УДК 339.9

JEL Index: F 15

Ataul Karim Rukon

Атаул Карім Рукон

\title{
IMPACT OF INNOVATION ON ECONOMIC GROWTH \\ IN THE BALTIC SEA REGION (BY WAY OF EXAMPLE OF STUDIES \\ FOR LATVIA AND DENMARK)
}

\author{
ВПЛИВ ІННОВАЦІЙ НА ЕКОНОМІЧНЕ ЗРОСТАННЯ \\ В РЕГІОНІ БАЛТІЙСЬКОГО МОРЯ (НА ПРИКЛАДІ ДОСЛІДЖЕНЬ \\ ДЛЯ ЛАТВІї І ДАНІї)
}

The theses provide aspects of the impact of innovation on the country's economic growth. The features of the innovation development of the Baltic Sea economies (by way of example of studies for Latvia and Denmark), namely, a global index of innovation in the countries, are examined. The influence of innovation costs of the countries on economic development (gross domestic product) is studied. The areas of innovation development to enhance the competitiveness of the Baltic Sea economies are suggested.

Keywords: innovation, innovation costs, economy, economic development, gross domestic product, analysis.

Introduction: At the present stage of development of the society innovation is an integral part of the effective functioning of the economy. Providing a basis for further economic growth, innovation is also a characteristic of welfare of the country as a whole. Today, innovation is the basis for economic development. This is not only high-tech and sophisticated scientific discoveries. There are also social, business, management, marketing, organizational and other innovations that do not require high finance, but only a more effective and creative application of knowledge [5, p. 24].

Based on the empirical studies the scientists have concluded that the scientific and technological progress is the main factor of economic growth. For example, R. Solow is the author of the macroeconomic model based on the contribution of the technological variable in the economic growth. R. Solow model is based on the Cobb-Douglas industrial function, it includes technological advances on par with capital and labour. This means that a country that has a higher rate of technological growth shall have a high standard of life [4, p. 42]. In addition, the impact of innovation development on economic development is supported by the Harrod-Domar model where the rate of growth of national income depends on the rate of capital accumulation (i.e. investment and innovation contributions) and capital intensity of the national income growth, as well as the model by P. Romer, which defined a significant impact of the intellectual capital and innovation on the level of the country's GDP [3].

Basic theoretical and practical provisions: The theoretical provisions of impact of innovation on the economic development are based on research of many theorists of innovation (Table 1).

For example, the essence of innovation theory of J. Schumpeter is that economic development is due not only to increase in national reserves, the means of production, but also to own redistribution of the means of production owned by the old combinations, in favor of the new ones [1].

The economic growth of the industrial age, according to S. Kuznets, is a result of the accelerated development of science: 'the mass use of technological innovations that make, to a significant extent, the essence of modern economic growth, which is closely connected with the further progress of science, that in turn forms the basis for further technical progress' [3].

C. Freeman combines innovative ideas with the problems of employment and social aspects. His research has shown that a central factor in the formation of long-term fluctuations in all spheres of economic life is innovation, however, employment is not only a consequence, but also a "kind of switch" of the economic activity [3].

Summing up the theories of innovation and their impact on economic development, it can be concluded that according to theorists of economics, innovation and technological development is of a 
cyclical nature and can produce profound structural changes in the economic, social and political spheres, and economic stagnation, in turn, may give rise to a new wave of innovation.

If we analyze the practical side of innovation and economic development of the economies of the Baltic Sea region, it should be noted that the EU countries have accumulated the broadest experience in the development of innovative cooperation. Stimulation of innovative development is carried out with the help of a number of interrelated and complementary channels, including The R \& D Framework Program, Eureka Program, and Structural Funds.

Table 1

Theoretical provisions of impact of innovation on the economic development*

\begin{tabular}{|c|c|c|}
\hline Stage & Researchers & Theoretical provisions \\
\hline $\begin{array}{l}\text { Fundamental stage } \\
10-40 \text {-s of the } 20^{\text {th }} \\
\text { century }\end{array}$ & $\begin{array}{l}\text { N. Kondratev, P. Sorokin, } \\
\text { M. Tugan-Baranovsky, } \\
\text { J. Schumpeter }\end{array}$ & $\begin{array}{l}\text { Economic development is a change in the trajectory } \\
\text { along which economic turnaround was carried out } \\
\text { before. Thus, if the production is a combination of } \\
\text { available things and forces, then a production of } \\
\text { something new is the creation of various combinations } \\
\text { of the same forces and things. }\end{array}$ \\
\hline $\begin{array}{c}\text { Detailing stage } \\
40-70 \text {-s of the } 20^{\text {th }} \\
\text { century }\end{array}$ & $\begin{array}{l}\text { G. Bernal, S. Kuznets, } \\
\text { P. Solow, B. Twiss }\end{array}$ & $\begin{array}{c}\text { Economic growth and development of the industrial } \\
\text { era is a consequence of the accelerated development of } \\
\text { science: the massive use of technological innovations, } \\
\text { which in turn forms the basis for further technical } \\
\text { progress }\end{array}$ \\
\hline $\begin{array}{c}\text { Theoretical } \\
\text { breakthrough } \\
\text { Middle } 70 \text { - }- \text { late } 20^{\text {th }} \\
\text { century }\end{array}$ & $\begin{array}{l}\text { A. Anchishkin, } \\
\text { Ya. Van Dane, S. Glazev, } \\
\text { O. Golichenko, B. Kuzyk, } \\
\text { B. Lundvall, G. Mensch, } \\
\text { S. Metcalfe, R. Nelson, } \\
\text { C. Freemen }\end{array}$ & $\begin{array}{l}\text { At the stage of depression the economy becomes } \\
\text { structurally ready for the transition to the new basic } \\
\text { innovations, it is in this moment that the clusters of } \\
\text { basis innovation are formed. }\end{array}$ \\
\hline $\begin{array}{c}\text { Modern stage } \\
\text { Early } 21^{\text {st }} \text { century - } \\
\text { present time }\end{array}$ & $\begin{array}{l}\text { R. Ayres, K. Watanabe, } \\
\text { Ch. Vessner, G. Itkovits, } \\
\text { L. Leydesdorfa, } \\
\text { G. Khorovitt, K. Fakuda }\end{array}$ & $\begin{array}{l}\text { The main purpose of innovation development should } \\
\text { be the establishment of stability, which requires the } \\
\text { achievement of three states - stability (invariability of } \\
\text { ecosystem in the conditions of interference), flexibility } \\
\text { (the ability to fast recovery and return to the original } \\
\text { state) and functional redundancy (the ability to } \\
\text { perform the functional process at a given speed } \\
\text { regardless of the interference). }\end{array}$ \\
\hline
\end{tabular}

Source: [1].

According to EU studies, by some indicators characterizing the newly industrialized countries, Denmark is among the leaders of the EU, namely in terms of indicators characterizing the degree of development of human resources, obtaining new knowledge, innovation cooperation and venture capital. But Denmark lags slightly behind Sweden and Finland in respect of $\mathrm{R} \& \mathrm{D}$ funding, the creation of new companies, the development of the education system, cooperation between universities and enterprises [6]. Denmark belongs to the EU countries, receiving most (per capita) EU funds for research programs, but these funds are not adequately materializeв in commercial projects. Denmark's share for the period 2007-2011 was $2.30 \%$ of all EU funds allocated for research programs, while in 2003-2006 the Danes received 2.38\% of the funds. This is due to the fact that the EU has recently prioritized the accelerated development of information and communication technologies, as well as fundamental studies which are not strength of the Danes [7, p. 55].

In Latvia, on the contrary, despite the work done, in general, it may be noted that the innovation policy ranks the weakest one among the EU countries. The data of Innovation Union Scoreboard 2014 confirm that Latvia is on the penultimate place in the EU. It is in the Modest Innovators group with innovation activity lower than the EU average. Innovation in Latvia does not grow at a constant rate, in 2013, in particular because of the deterioration of efficiency in the field of patent applications, there has been a decrease in innovation performance [13]. If we analyze the dynamics of the Global Innovation Index of INSEAD, Denmark rates $11^{\text {th }}$, and Latvia ranks $43^{\text {rd }}$ in 2015 (Figure 1). 


\section{Research findings and their assessment:}

Consequently, Denmark is a leader in innovation. Its effectiveness of innovation has increased steadily up to 2014 Performance in relation to the EU is increasing. The country is actively developing intellectual assets, research systems, ties and entrepreneurship, as well as high economic effect of the introduction is evident.

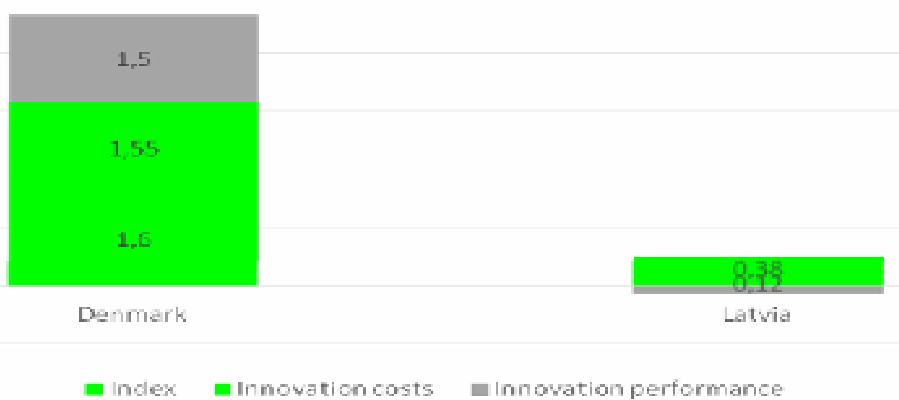

Figure 1. Structure of the Global Innovation Index of INSEAD of Denmark and Latvia in 2015* *Source: [2]

Latvia, on the contrary, is a modest innovator. Although the effectiveness of innovation has increased in 2014. The country is actively developing human resources and intellectual capital, investment in the private sector (firms) and intellectual assets. As noted earlier, Latvia ranks one of the last in the EU by the ratio of expenditures for research and development (R \& D) to GDP. The expenditures for R \& D are low, because capacity to perform is low. The EU, in its recommendations for the Latvian National Reform Programme, notes that only $10.4 \%$ of research institutions in the country can be considered as high-level research centers. For comparison, in the EU (28) the average index amounts to $23.7 \%$. It's quite a sad fact, and a challenge that must receive much more attention than has been received so far, is a significant stumbling block for the country's future growth [9] (Table 2).

Table 2

The analysis of innovative development of Denmark and Latvia in 2011-2015*

\begin{tabular}{|c|c|c|c|c|c|}
\hline & Indicators & 2011 & 2012 & 2013 & 2014 \\
\hline \multicolumn{4}{|c|}{ Denmark } \\
\hline 1 & Expenditures for innovation by sectors of activity, per capita, euro & 1,312 & 1,360 & 1,392 & 1,413 \\
\hline 2 & Gross Domestic Product, mln. euro & $7,299.1$ & $7,589.5$ & $7,803.1$ & $7,951.5$ \\
\hline \multicolumn{2}{|c|}{ Innovation Union Scoreboard Index } \\
\hline 3 & Summary Innovation Index (SII) time series & 0.696 & 0.718 & 0.728 & 0.736 \\
\hline 4 & Human resources & 0.620 & 0.605 & 0.635 & 0.631 \\
\hline 5 & Research systems & 0.829 & 0.800 & 0.822 & 0.823 \\
\hline 6 & Finance and support & 0.719 & 0.729 & 0.717 & 0.797 \\
\hline 7 & Firm investments & 0.564 & 0.569 & 0.543 & 0.513 \\
\hline 8 & Linkages \& entrepreneurship & 0.932 & 0.831 & 0.836 & 0.767 \\
\hline 9 & Intellectual assets & 0.845 & 0.828 & 0.840 & 0.892 \\
\hline 10 & Innovators & 0.558 & $0, .632$ & 0.702 & 0.585 \\
\hline 11 & Economic effects & 0.635 & 0.671 & 0.669 & 0.760 \\
\hline \multicolumn{5}{|c|}{ Latvia } \\
\hline 12 & Expenditures for innovation by sectors of activity, per capita, euro & 67.8 & 71.7 & 69.1 & 81.3 \\
\hline 13 & Gross Domestic Product, mln. euro & 140.7 & 146.5 & 139.7 & 162.8 \\
\hline \multicolumn{2}{|c|}{ Innovation Union Scoreboard Index } \\
\hline 14 & Summary Innovation Index (SII) time series & 0.225 & 0.225 & 0.221 & 0.272 \\
\hline 15 & Human resources & 0.451 & 0.451 & 0.554 & 0.586 \\
\hline 16 & Research systems & 0.053 & 0.083 & 0.089 & 0.102 \\
\hline 17 & Finance and support & 0.250 & 0.375 & 0.392 & 0.326 \\
\hline 18 & Firm investments & 0.369 & 0.111 & 0.105 & 0.415 \\
\hline 19 & Linkages \& entrepreneurship & 0.061 & 0.103 & 0.134 & 0.088 \\
\hline 20 & Intellectual assets & 0.309 & 0.330 & 0.225 & 0.368 \\
\hline 21 & Innovators & 0.035 & 0.123 & 0.116 & 0.091 \\
\hline 22 & Economic effects & 0.262 & 0.220 & 0.225 & 0.261 \\
\hline
\end{tabular}

*Source: $[9,10-14]$. 
If the dynamics of the expenditures for innovation and GDP is estimated, a positive trend for the whole country can be seen, but the level of innovation and consequently economic development is significantly higher in Denmark (7,951.5 million euro GDP in 2015 in Denmark to 162.8 million euro GDP in 2015 in Latvia) (Table 2, Figure 2).

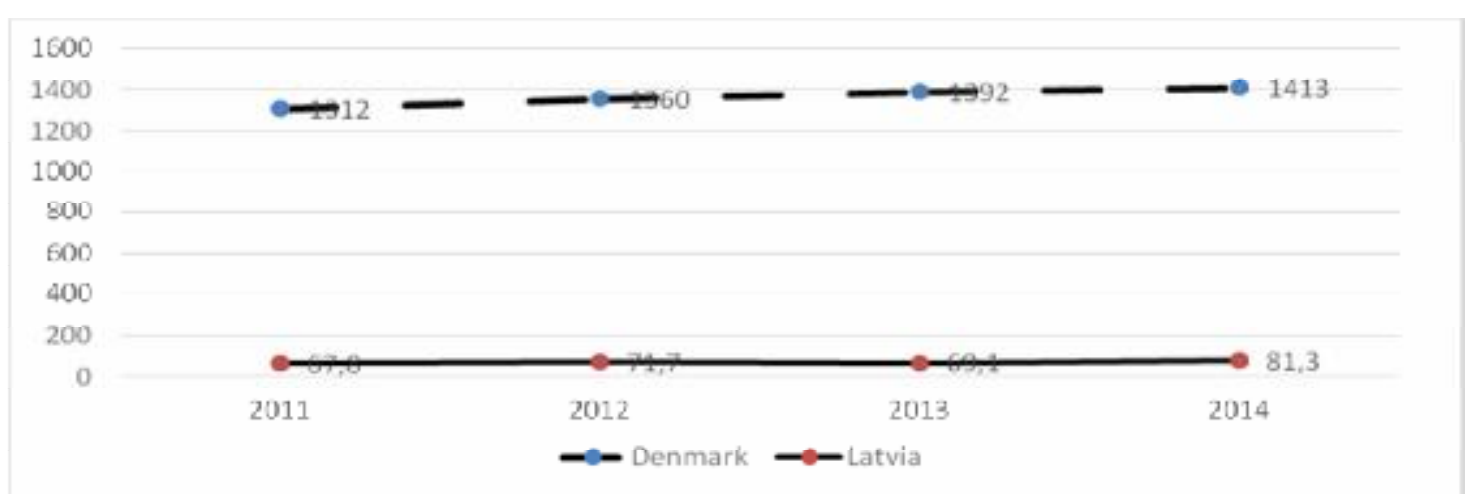

Figure 2. Expenditures for innovation by sectors in Denmark and Latvia for 2011 - 2014*

*Source: [9].

If the relationship between innovation and economic development is studied in Denmark and Latvia through the search for the correlation dependences by Pearson criterion, we can get the following data:

Pearson's correlation coefficient for Latvia: $\quad r_{x y}=195 /(10.77 x 18.405)=0.984$.

Pearson's correlation coefficient for Denmark: $\quad r_{x y}=37308.5 /(76.123 \times 490.399)=0.999$.

If the relationship between innovation investment and economic effect in Denmark and Latvia is studied through the search of correlation dependencies using Pearson criterion, we can get the following data:

Pearson's correlation coefficient for Latvia: $\quad r_{x y}=238 /(8.23 \times 9.57)=0.3589$.

Pearson's correlation coefficient for Denmark: $r_{x y}=1788 /(89.455 x 12.988)=0.8385$.

It follows that expenditures for innovation significantly affect the GDP volume in these countries, and economic development as a whole. In addition, a substantial economic effect of investment in innovation in Denmark, and little impact in Latvia can be found, which explains the low levels of innovation and economic development.

Conclusions, suggestions: For the successful development and increased innovation competitiveness, improving economic development of the Baltic Sea economies the following areas of work are fundamentally important:

1. Further promotion of innovation in the companies (including the necessary tax incentives for research and development ( $\&$ \&), as well as other types of incentives, such as accelerated depreciation, and other regulations that encourage investment in major economic blocks that determine the growth of the economy, such as development of human resources, are also important).

2. The development of the "digital economy" (it is necessary not only to increase public investment in IT in areas such as health care, energy systems, transport, public administration, education, but also to create an effective regulatory framework to encourage, rather than restrict the development of "digital" economy).

3. Support of all the institutions required for innovation. It is important to increase funding not only for university research, but also for the institutions that promote commercialization of scientific developments.

4. Effective public policy in the field of innovation.

5. Openness to immigration of highly qualified personnel which can be a source of new ideas and innovations. The strengths, which are an important component of economic development in the context of the investment in innovation, include: improving economic structure, significant reduction in material and power inputs, a relatively high level of education among the population, traditionally high scientific potential able to solve the most complex technical challenges, high capacity for inventive activity, traditionally strong role of the state in research and innovation activity. 


\section{References}

1. Varenik, K. A. (2013), "Theory of innovation as key direction of scientific researches of the $20^{\text {th }}$ century", Current Problems of Science and Education, No. 5, available at: http://www.science-education.ru/ru/article/view?id=10169

2. "Global Innovation Index", available at: https://www.globalinnovationindex.org/content/page/GII-Home

3. Grigorev, A. D., Zimin, A. D. "Theory of innovation: formation and development", available at: http://www.innoros.ru/publications/analytics/12/teorii-innovatsii-formirovanie-i-razvitie

4. Dagaev, A. (2001), "New models of economic growth with endogenous technological process", World Economy and international Relations, No. 6, pp. 40-51.

5. Druker, P. F. (2007), Business and Innovations. Trans. from Eng. and ed. by K. S. Golovinskiy, Vilyams LLC, Moscow, $432 \mathrm{p}$.

6. "Innovations: Danish style", available at: http://www.sice.ru/cnts/1822.html

7. "Periodic review of innovation in Europe, America, Asia and Africa" (2012), the CIS, No. 5, March, 61 p.

8. "Rating of innovation: in the overall ranking Russia ranks $35^{\text {th }}$, by the dynamics of innovations $-8^{\text {th }}$, available at: http://www.trainings.ru/library/articles/?id=11480

9. "Eurostat statistics explained", available at: http://ec.europa.eu/eurostat/statistics-explained/index.php/Innovation_statistics.

10. "Innovation Union Scoreboard 2012", available at: https://ec.europa.eu/research/innovation-union/pdf/state-of-theunion/2012/state_of_the_innovation_union_report_2012.pdf

11. "Innovation Union Scoreboard 2013", available at: https://ec.europa.eu/growth/tools-databases/eip-rawmaterials/en/system/files/ged/69\%20Innovation\%20Union\%20Scoreboard\%202013_en.pdf

12. "Innovation Union Scoreboard 2014", available at: http://www.merit.unu.edu/eu-innovation-union-scoreboard2014/

13. "Innovation Union Scoreboard 2015", available at: http://ec.europa.eu/growth/industry/innovation/factsfigures/scoreboards/files/ius-2015_en.pdf

\section{Атаул Карім Рукон}

\section{ВПЛИВ ІННОВАЦІЙ НА ЕКОНОМІЧНЕ ЗРОСТАННЯ В РЕГІОНІ БАЛТІЙСЬКОГО МОРЯ (НА ПРИКЛАДІ ДОСЛІДЖЕНЬ ЛАТВІї І ДАНІї)}

У статті розглянуто аспекти впливу інновацій на економічне зростання крайни. Досліджено особливості інновачійного розвитку економіки регіону Балтійського моря (на прикладі досліджень Латвії і Данії), зокрема, глобальний індекс інновачій у крайнах. Вивчено вплив інновачійних витрат країн на економічний розвиток (валовий внутрішній продукт). Запропоновано напрями інноваційного розвитку з метою підвищення конкурентоспроможності економіки регіону Балтійського моря.

Ключові слова: інновачія, інноваційні витрати, економіка, економічний розвиток, валовий внутрішній продукт.

Рецензенти: д.е.н., професор Коломицева О. В., зав. кафедри економічної кібернетики та маркетингу, Черкаський державний технологічний університет, д.е.н., професор Шпильова В. О., ЧФ ПВНЗ «Східнєвропейський університет». 